\title{
OBESITY AND VASCULAR DYSFUNCTION
}

\author{
Phoebe A. Stapleton ${ }^{1,3}$, Milinda E. James ${ }^{2,3}$, Adam G. Goodwill 2,3 , and Jefferson C. \\ Frisbee $^{2,3}$ \\ 1Division of Exercise Physiology, West Virginia University School of Medicine, Morgantown, WV 26506 \\ 2Department of Physiology and Pharmacology, West Virginia University School of Medicine, Morgantown, \\ WV 26506 \\ 3 Center for Interdisciplinary Research in Cardiovascular Sciences, West Virginia University School of \\ Medicine, Morgantown, WV 26506
}

\begin{abstract}
One of the most profound challenges facing public health and public health policy in Western society is the increased incidence and prevalence of both overweight and obesity. While this condition can have significant consequences for patient mortality and quality of life, it can be further exacerbated as overweight/obesity can be a powerful stimulus for the development of additional risk factors for a negative cardiovascular outcome, including increased insulin resistance, dyslipidemia and hypertension. This manuscript will present the effects of systemic obesity on broad issues of vascular function in both afflicted human populations and in the most relevant animal models. Among the topics that will be covered are alterations to vascular reactivity (both dilator and constrictor responses), adaptations in microvascular network and vessel wall structure, and alterations to the patterns of tissue/organ perfusion as a result of the progression of the obese condition. Additionally, special attention will be paid to the contribution of chronic inflammation as a contributor to alterations in vascular function, as well as the role of perivascular adipose tissue in terms of impacting vessel behavior. When taken together, it is clearly apparent that the development of the obese condition can have profound, and frequently difficult to predict, impacts on integrated vascular function. Much of this complexity appears to have its basis in the extent to which other co-morbidities associated with obesity (e.g., insulin resistance) are present and exert contributing effects.
\end{abstract}

\section{Keywords}

Adiposity; models of obesity; metabolic syndrome; vascular dysfunction; inflammation

\section{INTRODUCTION}

Obesity is a national and global epidemic [1,2], and ongoing investigation has demonstrated that the numbers of individuals categorized as overweight or obese have increased over the last three decades and are continuing to rise, especially in developed economies [3]. Obesity is defined by the Centers for Disease Control as a body mass outside the range of that which

Send Correspondence to: Jefferson C. Frisbee, Ph.D., Center for Interdisciplinary Research in Cardiovascular Science, Department of Physiology and Pharmacology, Robert C. Byrd Health Sciences Center, PO Box 9105, West Virginia University School of Medicine, Morgantown, WV 26505, Phone: (304) 293-6527, Fax: (304) 293-5513, Email: jfrisbee@ hsc.wvu.edu.

Publisher's Disclaimer: This is a PDF file of an unedited manuscript that has been accepted for publication. As a service to our customers we are providing this early version of the manuscript. The manuscript will undergo copyediting, typesetting, and review of the resulting proof before it is published in its final citable form. Please note that during the production process errors may be discovered which could affect the content, and all legal disclaimers that apply to the journal pertain. 
has been determined to predict healthy outcomes; a determination made through the use of the body mass index (BMI), which is based on height and weight, and which correlates strongly with an individual's adiposity. The BMI classification by the National Heart, Lung, and Blood Institute for adults (age 18-85) defines an individual as being overweight for BMI between 25 and 29.9, and obese for BMI greater than 30. The estimated economic impact of obesity, its "quality of life" implications and related treatment, cost Americans over 117 billion dollars in 2001, while the World Health Organization has estimated that the treatment of obesity represents up to $7 \%$ of total global health care expenditures [4].

Obesity is a complex pathology with interacting and confounding causes proposed from the environment, hormonal signaling patterns, adipogenic pathogens, genetic predispositions, adipokine receptor defects, and numerous behavioral aspects such as eating disorders, inadequate portion control, and decreased physical activity [5-16]. Although the etiology of obesity can be extremely complicated, a central imbalance in caloric homeostasis is the primary contributing factor to this condition [17].

The progression of obesity has been associated with an increased predisposition for the development of additional pathological conditions, including a wide array of cardiovascular disease risk factors (e.g., diabetes, hypertension, dyslipidemia, prothrombotic and proinflammatory environments), as well as the development of respiratory dysfunction (obstructive sleep apnea), arthritic disorders, and a wide array of adverse psychological conditions [18-24]. When multiple other cardiovascular disease risk factors, in addition to the progression of obesity, are present, this combination leads to the creation of a condition termed "metabolic syndrome", which can dramatically increase the likelihood of negative health outcomes in afflicted individuals [25-27].

\section{GENETIC FACTORS}

Nearly 400 genes have been associated with human obesity [28]. While genetic factors clearly play a key role in the development of obesity, few individuals afflicted with a rare dysfunctional gene express a profoundly obese or lean phenotype; therefore, the widespread frequency of obesity cannot be explained via a monogenic obesity model [12,28,29]. In addition, "susceptibility genes", or candidate genes that underlie the development of obesity have also been previously described in the literature [30,31]. These "susceptibility genes" may best be conceptualized as those genes promoting adiposity given the appropriate environmental conditions, which include physical activity and diet [32]. However, neither rare nor susceptibility genes can effectively explain the significant increases in both incidence and prevalence within world-wide populations, notably, the increase in obesity prevalence since 1990 [33]. It is more likely that the prevailing form of obesity can be described by numerous genes and gene-gene interactions, which under environmental influences, contribute to an obese phenotype [12].

\section{A MODEL FOR THE STUDY OF OBESITY}

The obese Zucker rat (OZR), offers a reliable animal model for the study of an obesity-based induction of metabolic syndrome. This genetic mutation $(f a-/ f a-)$ is autosomal recessive with a locus on chromosome 5, leading to improper encoding of the leptin receptor gene $[34,35]$. As such, heterozygotes $(f a-/ f a+)$ are generally not physiologically distinguishable from the control $(f a+/ f a+)$ lean Zucker rat (LZR). Due to the impairment of the leptin receptor, OZR manifests an impaired satiety reflex, resulting in a profound, consistent hyperphagia, from which the considerable obesity develops. With both hypertrophy and hyperplasia of adipocytes, OZR begins to manifest many of the characteristics of human obesity: moderate hypertension, hypertriglycemia, insulin resistance, and the evolution of a pro-inflammatory state; suggestive that OZR may represents a viable model to study human obesity [35-38]. 
The initiating stimulus for the development of obesity in OZR is a chronic hyperphagia, leading to an imbalance of caloric homeostasis, making the model extremely relevant to the general human population. The development of type II diabetes mellitus, following a prolonged period of hypertriglyceremia and insulin resistance, in addition to the development of a proinflammatory state within the OZR model, also mimics the human condition [39].

The $o b / o b$ mouse is an additional well established model for the study of human obesity that owes its pathology to a deficiency in leptin production as a result of a genetic mutation [40]. The $o b / o b$ manifests a pronounced non-insulin dependent diabetes mellitus and obesity observed within 28 days of birth, when compared to their lean littermates [41]. The strain is used as a model for human obesity in a variety of pulmonary, cardiovascular, and metabolic function studies [42-44].

Canine models can viably mimic human obesity without genetic modifications through simple dietary manipulations. This model allows for accurate methods for metabolic assessment in vivo, longitudinal studies, and fat deposits assessment [45].

\section{VASCULAR DYSFUNCTION ASSOCIATED WITH OBESITY}

Many diagnosed co-morbidities have been positively correlated to overweight/obesity, translating across race, gender, and age. While dyslipidemia, glucose intolerance, insulin insensitivity, hypertension, pro-thrombotic and pro-inflammatory environments play an important in the pathophysiology of obesity, it is very difficult at this time to separate the disorders and the specific roles each play through the disease progression; therefore, these conditions will be referred to within the context of this review, but not specifically addressed.

\section{Vascular Disease/Coronary Artery Disease/Perfusion abnormalities}

Specific to cardiovascular health, a significant effect of obesity is the increase in the development of peripheral vascular disease, a condition identified by decreased perfusion to peripheral limbs and tissues, causing edema, and leading to a decrease in function and progressive loss of tissue viability [46]. In humans, this can lead to loss of mobility, chronic pain, and development of psychological depression [47]. Chronically, these complications can manifest with venous stasis leading to lower limb ulcerations, increases in venous thromboembolism, and a higher rate of pulmonary embolism [48,49].

Studies of the direct physiological effects of peripheral vascular disease have been limited in humans in the past due to the invasive nature of some procedures. However, ultrasound techniques with advanced Doppler technologies have translated to non-invasive means to investigate and track peripheral and coronary disease states [50,51]. Carotid intima-medial thickness (IMT) is a good predictor of adult obesity and cardiovascular events [52,53]. As subjects age, the cholesterol deposits in the macrophage foam cells of the vascular intima become more extensive, and the resulting plaques become linked to acute coronary syndromes; this thickening of the intima-medial layer is highly correlated with adiposity, plaque lesions, and future cardiovascular events [54-56].

In a recognized experimental model of metabolic syndrome, OZR, the perfusion of multiple tissues has been shown to be compromised [35-37,57]. The direct mechanism of this decrease in perfusion, found in both humans and the OZR, seems to be multi-faceted: a combination of altered responsiveness to vasodilator and vasoconstrictor mechanisms, changes to the mechanical properties of the perfusing arteries, or a limit in the density/number of available microvessels to supply the tissue [58]. 


\section{Vasodilation}

Conditions that result from obesity, such as metabolic syndrome, manifest compromised vasodilation in response to physiological or pharmacological challenges, for example, elevated metabolic demand or infusion of endothelium-dependent agonists. One of the most heavily studied endothelium-dependent mechanisms studied has been the changes associated with nitric oxide (NO) production and release from the endothelium [59,60]. In a 2006 study of humans by Van Guilder, obese subjects were observed to have a reduced reaction to the vasodilator acetylcholine after intra-arterial infusion, relative to age matched lean subjects, while there were no differences to an intra-arterial infusion of sodium nitroprusside, a direct NO donor [61]. Patients with metabolic syndrome also show blunted endothelium-dependent dilation responses to infused vasodilators, relative to control patients, while endotheliumindependent mechanisms remained intact [62]. These results have been shown in animal studies as well, as both OZR and lean rats fed a high fat diet have been shown to have an impaired vasodilatory response of isolated microvessels to endothelium-dependent $\mathrm{NO}$ agonists [63, 64].

This lowered response is mediated by a NO signaling mechanism which can lead to a condition that can also impact muscle cell proliferation, platelet aggregation, macrophage action, and inflammatory markers. The NO signaling mechanism is based upon a balance of NO production, via NO synthase and NO removal systems, which can include the presence of scavenging via reactive oxygen species. While NO synthase activity has been maintained, or possibly increased under obese conditions; however Eringa, 2007 shows a decreases in eNOS protein levels in resistance arteries, which may link obesity with several confounding disease states [65-68]. In addition, the obese animal has been shown to exhibit higher levels of oxidative stress markers than their lean counterpart [69-71]. These animal models of obesity have shown improvements in the patterns of vasodilator reactivity when treated with antioxidants such as vitamin $\mathrm{E}$, or an array of superoxide dismutase mimetics [72,73]. Thus the decreased levels of NO noted in obesity may primarily reflect an increased scavenging via reactive oxygen species, resulting in the production of substances such as peroxynitrite [71, 74]. When arachidonic acid is introduced to the system, vasodilatory responses are attenuated in both gracilis and spinotrapezious arterioles of the OZR in comparison to the LZR [73,75]. The impaired responses appear to operate partially via an elevation in oxidant stress, but additional signaling pathways independent of acute alterations in oxidant tone appear to also be involved.

Flow-mediated dilation initiates the release of endothelium-derived relaxing factors, causing an increase in vessel diameter and therefore an increase in volume perfusion [76]. This dilation, an endothelium-dependent mechanism, has been shown to be impaired in obese patients, due to changes within the endothelium, which may be strongly linked to signaling mechanisms associated with chronic and evolving inflammation [77]. Patients with metabolic syndrome have an impaired brachial artery flow-mediated dilation relative to normal control subjects while their response to an exogenous NO-donor was uncompromised [78]. Amelioration of the condition of metabolic syndrome through weight loss and exercise improves conduit reactivity, via brachial artery flow mediated dilation, although improvements to indices of resistance vessel reactivity are less sensitive to these improvements [78,79].

\section{Vasoconstriction}

Vasoconstriction is occasionally described in the literature as a non-vasodilation, or a decrease in a vasodilatory mechanism, specifically relating to a diminished NO production or signaling and leads to decreased muscle tissue perfusion. This is also the case within the realm of obesityrelated vasoconstriction. 
Vasoactivity and vascular tone are based on a balance of circulating vasodilatory and vasoconstrictive factors; diabetic patients have shown increases in vascular constrictive factors and decreases in vasodilatory agents [80]. Vasoconstriction to angiotensin-II is amplified in the obese animal (OZR), while reactivity to norepinephrine remains similar to the reactivity of the LZR; a similar pattern of reactivity has also been described in humans [81]. Metabolic syndrome patients have shown increased levels of endothelin-1 (ET-1), a potent vasoconstrictor, and an overall increase in response to vasoconstrictive agonists [82,83]. The profound impact mediated by prostanoid species and other metabolites of arachidonic acid on basal perfusion/resting vascular tone as well as on hyperemic responses has been well established [84-87]. More recently, increased levels of vasoconstrictor prostanoids have also been suggested as a possible mechanism for the decreased vascular perfusion and dilator reactivity within obesity and the metabolic syndrome [88]. In the OZR, an increase in vasodilation was noted when the prostaglandin $\mathrm{H} 2 /$ thromboxane $\mathrm{A} 2$ receptor antagonist SQ-29548 was administered, suggesting that a chronic basal vasoconstrictor influence, mediated via the PGH2/TxA2 receptor may contribute to impairments in organ perfusion and dilator reactivity [75]. These changes to endothelial vasoconstrictor response with obesity may show an initial effect, while neurological mechanisms may show a longer lasting systemic role [89].

Neural mediated vasoconstrictors have also been shown to play a part in basal vasoconstriction in hypertensive patients, due to a hyperactivity of the sympathetic nervous system [90]. Baseline and maximal diameters and arteriolar blood flow of obese animals are reduced compared with the lean counterparts, suggesting an increase in adrenergic tone and structural mechanisms to increase vascular resistance [91]. Systemic adrenergic activity has not been found to be elevated when normalized to blood volume, instead, these changes may indicate a redistribution and possible remodeling of adrenergic activity within the obese animal, allowing increases in perfusion of the mesenteric system and decreases in perfusion of the skeletal muscles [92].

\section{Functional Hyperemia/Muscle Blood Flow}

Functional hyperemia is defined as an increase in tissue/organ perfusion in response to metabolic demand. This increase can be modified at rest or with activity through the release of metabolic factors from skeletal muscle, myogenic responses, conducted vasodilation, and the release of the endothelium-derived factors nitric oxide and prostaglandins [72]. Humans and animal models, in a condition of obesity, have shown a reduced blood flow response to exercise or any increase in local metabolic activity [72,93].

In addition to impairments to vasodilator reactivity discussed above, and the potential for enhanced vasoconstrictor responses to constrain perfusion, myogenic (intralumenal pressureinduced) control of the blood vessel may be augmented in obese animals, as OZR are seen to respond to these changes with a significantly greater constriction than in lean animals. It has been hypothesized that the generation of peroxynitrite, through the progressive scavenging of nitric oxide by pressure-induced increases in superoxide anion may play a key role in antagonizing calcium-activated potassium channels, thus enhancing myogenic activation [71, 94,95].

Sympathetic neural hyperactivity, associated with obesity, has been shown to reduce vasodilation, increase vascular resistance and decrease blood flow [96,97]. In addition, it seems that obesity may be associated with either an increased reactivity to adrenergic neurotransmitters, also leading to a reduction in blood flow or possibly an increased sympathetic nerve activity as a result of obesity [98-101]. 


\section{Microvessel Density/Rarefaction}

In addition to a constrained functional hyperemia, and therefore the inability to provide an adequate blood supply to active tissue in an obese setting, there is an additional restriction within the peripheral tissue that becomes increasingly relevant with elevated metabolic demand. With the development of the obesity-associated metabolic syndrome, previous studies have demonstrated that a progressive microvascular rarefaction (a reduction in microvascular density) develops within multiple tissues/organs [58,102-104]. This rarefaction can lead to tissue hypoxia and ischemia leading to a predisposition to cellular dysfunction, in addition to, reductions in nutrient transport, blood supply, and exchange capabilities.

\section{Capillary Recruitment}

Insulin action and glucose transport can be varied by skeletal muscle capillary recruitment, and while specific mechanisms associated with insulin-mediated capillary recruitment are not fully understood, the presence of "obesity-mediated insulin resistance" has been demonstrated to impair this process $[105,106]$. Additionally, isolated vascular smooth muscle cells from obese animals and subjects demonstrate a profound impairment in insulin-signaling mechanisms [107,108]. Addressing this, it has recently been hypothesized that the presence of excess abdominal adipose tissue may interrupt the glucose-insulin signaling/transport mechanisms of surrounding tissues and organs by an increased production of fatty acid metabolites, adipokines and chemokines, thus leading to an impaired capillary recruitment via insulin-mediated avenues, as described in obese humans and obese Zucker rats [106,109,110].

\section{Vascular Structure and Remodeling}

In addition to microvessel number and recruitment disturbances, structural alterations also take place in the environment of obesity. These modifications are described and well known within the diabetic literature, but the appearance of these changes is now being expressed in association with peripheral artery disease and metabolic syndrome, a link that could be mediated by the theory of an "obesity-mediated insulin resistance" [106,111,112].

Clinical and basic science studies have demonstrated that changes in insulin resistance and increases in BMI are frequently associated with stiffness of resistance arterioles, thickening of basement membranes, and increases in diameter [113,114]. Increases in the level of insulin can contribute to increased arterial wall thickness by direct trophic effects of smooth muscle cells, by generation of reactive oxygen species, protein kinase $\mathrm{C}$, and by activation of NF- $\mathrm{kB}$, which acts to stimulate growth and proliferation of vascular smooth muscle cells. There has also been a positive correlation between structural peripheral vascular changes and insulin resistance [115]. The documented decrease in microvessel density found with obesity and its consequences could also mediate this correlation.

In structural remodeling, the factors which influence upstream must be separated from the local alterations to microvessel environment. Obesity, diabetes, insulin resistance, atherosclerosis, hypertension, and stenosis are all conditions that have significant effects on conduit arteries, but have a severe effect on the autoregulation of the microvasculature; thus, leaving it severely compromised, thereby threatening downstream vessels and surrounding tissues with ischemia and hypoxia. In an attempt to accommodate, the microvessel creates a thickened basement membrane to acclimatize to the increase in pressure and a transition in the shunt system normally used to redirect blood during meals or exercise $[111,116]$. As the disease progression of metabolic syndrome continues, the walls of the microvessels begin to atrophy, decreasing the size of the lumen, decreasing the ability to shunt, thereby increasing the risk of ischemia, and increasing the risk of peripheral vascular disease [111]. 


\section{Coronary Dysfunction}

The continuous supply and distribution of fully oxygenated blood throughout the myocardium is essential for maintaining cardiac performance, with any significant ischemia leaving the myocardial mass at profound risk for injury and dysfunction. While resting coronary perfusion shows little difference with increasing BMI, a reduced capacity for perfusion with elevated metabolic demand has the potential to widen the gap between metabolic supply and demand, putting the heart at risk of ischemic injury [89].

Disease states such as obesity and insulin resistance can cause or exacerbate a series of impairments within control mechanisms of the coronary vasculature, including endothelial function, neurohumoral control, and smooth muscle ion channel behavior, while additional effects of obesity can include an increased inflammatory state, vascular permeability, cell adhesion and an increased predisposition for coagulation events [59,89,117,118]. Endocrine and neural control of the vasculature may be modified due to an increase in activity of the renin-angiotensin system [119]. Additionally, recent studies have suggested that altered function of ion channels and calcium handling within the vascular smooth muscle may contribute to the dysfunction expressed in the coronary vasculature of obese dogs [89].

\section{Inflammation}

Attempting to understand the relationship between obesity and inflammation can be a daunting task in that inflammation is simultaneously its own independent risk factor while also being an integral component in the pathways by which other obesity related risk factors manifest themselves as disease. Adipokines, cytokines secreted by adipose tissue, released in excess in an obese state can create an environment susceptible to inflammation. In obese animal models, many adipokines are amplified above a normal level, but are lower than a traditionally described inflammatory state, leading many investigators to describe a chronic state of lowgrade obesity-associated inflammation [120,121]. These white adipose derived signaling molecules can be classified as non-esterified fatty acids (NEFA), cytokines, chemokines, or hormones and can influence insulin dependant and independent signaling, insulin mediated glucose uptake and numerous aspects of vascular function $[18,58,89,106,122,123]$. The inflammatory markers to be briefly covered in this review include: TNF $\alpha$, endothelin, angiotensinogen, adiponectin, MCP-1, IL-1 $\beta$, IL-8, Leptin, IL-6, and resistin. It is important to note that this list constitutes only a sampling of white adipose derived signaling molecules and further fails to account for a great deal of the cross talk between the signaling molecules. The scope of the topic would demand a separate review of its own and thus, we only hope to present a general picture of the crucial role of inflammation in the pathogenesis of obesity.

Levels of TNF $\alpha$ correlate strongly with adiposity and are associated with impaired capillary recruitment in man, diminished vasodilatory effect in muscle resistance arteries of rats, diminished insulin-mediated glucose uptake in rat skeletal muscle, elevated adhesion of polymorphonuclear leukocytes (PMNs) to microvessels, induction of oxidative stress, upregulation of endothelial cell adhesion molecules, and reduced barrier function $[18,89,122$, 123]. TNF $\alpha$ is produced by neutrophils, macrophages and adipocytes with its production apparently elevated in perivascular adipose tissue leading researchers to believe that the measurements of circulating TNF $\alpha$ may give deceptively low concentrations relative to true site-of-action concentrations $[122,123]$. TNF $\alpha$, which works primarily by modifying the effects of insulin, is one of a group of signaling molecules capable of acting directly on the vascular endothelium and the net effect of its apoptotic and pro-inflammatory properties is endothelial dysfunction and decreased insulin sensitivity by the vascular endothelium $[18,122,123]$.

Antiotensinogen is expressed in high levels by visceral adipose tissue with lower levels of expression evident in subcutaneous fat [18]. Angiotensinogen serves as the precursor to 
angiotensin II, a powerful vasoconstrictor product of the renin-angiotensin system (RAS). At low levels, the vasoconstriction elicited by angiotensin II is mild and predominately manifested in large, conduit vessels [89]. Chronic activation of the renin-angiotensin system results in drastically elevated angiotensin II levels, leading to significant vasoconstrictive response and ultimately resulting in inflammation, vascular remodeling, thrombosis and plaque rupture $[18,89]$. The effects of angiotensin II are mediated via a cognate receptor, AT1. Interaction between angiotensin II and AT1 results in the previously stated consequences, mediated through RAS, along with increased oxidant stress at the level of the vascular endothelium [89]. The oxidant stress sensitive transcription factor NFאB is in turn activated leading to increased expression of the adhesion markers VCAM-1, ICAM-1, E-selectin and IL-8 resulting in increased rolling and adherence of leukocytes within the microcirculation [18].

Another signaling molecule capable of exerting effects directly on the vascular endothelium is adiponectin [122]. Unlike TNF $\alpha$, adiponectin is associated with improved endothelial function and positive cardiovascular outcomes $[18,106,122,123]$. Adiponectin is inversely correlated with adiposity and reduces the production of pro-inflammatory cytokines, TNF $\alpha$, and IL- 6 while concurrently increasing expression of the anti-inflammatory cytokines IL-10 and IL-1 receptor antagonist $[18,123]$. The direct effect of adiponectin on the vascular endothelium is the phosphorylation of eNOS at Ser1177, resulting in increased production of NO [122]. Adiponectin also aids in the prevention of leukocyte rolling in adhesion by reducing expression of endothelial cell adhesion molecules, possibly through an inhibition of NFkB [18].

The primary of function of leptin is classically considered to be regulation of appetite and body weight. This regulation is achieved through diminished appetite via suppression of neuropeptide $\mathrm{Y}$ by leptin at the hypothalamus with concurrent increase in melanocytestimulating hormone (i.e. satiety signaling) [123]. Leptin action, when associated with the leptin receptor in the vascular endothelium, enhances endothelin-1 production, elicits oxidative stress, and promotes angiogenesis $[18,123]$. Leptin has also been shown to enhance platelet aggregation, which may lead to platelet adhesion [18]. Leptin levels are directly proportional to adiposity and leptin is capable of exerting a vasodilatory effect on coronary and resistance arteries through endothelium-dependant phosphorylation of eNOS at Ser1177 or directly through uncharacterized endothelium-independent mechanisms [124,125]. Interestingly, leptin levels are elevated in human obesity leading some scientists to postulate the existence of leptin resistance, with $\mathrm{C}$ reactive protein (CRP) identified as a possible source of disruption of intracellular leptin signaling [122].

IL-6 is the primary regulator of CRP, with elevations in IL-6 leading to CRP mediated inhibition of eNOS, angiotensin-stimulated production of reactive oxygen species, increases in vascular permeability, elevated expression of adhesion molecules and thrombus formation $[18,122,123]$. IL-6 levels are directly proportional to adiposity and elevations result in direct impairments of endothelial function [18].

Resistin is a product of white adipose tissue though its expression in humans borders on undetectably low levels [18]. It has no clear correlation with adiposity though it has been implicated in adipogenesis and in the development of insulin resistance [18,123]. Resistin stimulates the production of TNF $\alpha$, IL- 6 and MCP-1 through NFKB with a concomitant decrease in the production of IL-10 [18]. Additionally, resistin elevates ET-1 release and expression of adhesion molecules and has been strongly correlated with insulin resistance and chronic kidney disease [122].

Endothelin exerts its potent vasoconstrictor effects through the endothelin type A (ETa) receptor. ET-1 has been recognized as a mediator of endothelial dysfunction in coronary and 
peripheral artery diseases due to the prolonged vasoconstrictive effect of ET-1 resulting in a decreased coronary blood flow reserve in humans. Plasma ET-1 concentrations correlate with adiposity and show further correlations with elevated HbAlc (glycosylated hemoglobin, considered to be indicative of glycemic control over extended periods of time), hypertriglyceridemia and increased waist/hip ratio [89].

Both NFKB and TNF $\alpha$ have been shown to increase production of MCP-1, a signaling molecule whose function through the CCR-2 receptor is, primarily, the recruitment of macrophages into tissues at sites of inflammation [123]. MCP-1 increases monocyte adhesion to the vascular endothelium, has been describes as anti-angiogenic and has a strong inverse correlation with NO bioavailability [58,122]. These effects are similar to those seen by increased IL-1 $\beta$ or IL-8 expression though they are achieved through a different mechanism [58,122,123].

It rapidly becomes apparent that inflammation and obesity is a winding road, with most signaling molecules modifying the actions of other signaling molecules which in turn propagate the process. In some cases, adiposity leads to increased production of a cytokine whereas in other cases, production of a cytokine leads to increased adiposity, leads to increased cytokine production. For this reason, inflammation can never truly be solely a risk factor or an outcome of obesity; rather, it is a multifactorial contributor to the overall pathophysiology of the condition.

\section{Perivascular Adipose Tissue}

Adiposity can be described by location, upper body/abdominal or lower body; and most confounding disease states related to obesity are those with profound visceral adipose deposits, within the upper body [126]. This visceral adipose may act to impair function via mechanical compression or enhanced adipokine secretions [127]. The perivascular adipose tissue (PAT) is described as the adipose tissue which surrounds local vasculature, specifically but not limited to the peri-aortic adipose tissue and that surrounding the coronary arteries [127]. There are other adipose deposits, including epicardial adipose tissue, and intramuscular adipose tissue, which produce specific adipokines and have access to local vasculature [122]. Overall a net decrease in vascular tone and relaxation has been attributed to the perivascular adipose tissue of the aorta and mesenteric arteries, as the removal of PAT from these tissues led to an enhanced contractile response [128-130].

In the past, this vascular adventitia has had stabilizing properties, but under further investigation, there are significant endocrine properties that may be mediated by PAT [131134]. In addition to endocrine properties, PAT has been shown to regulate vascular tone of the smooth muscle via release of perivascular adipocyte-derived relaxation factor (PVAT) which acts to hyperpolarize the smooth muscle and promoting vasodilation [134]. PVAT has also been shown, in obese hypertensive animals, to react with various vasoconstrictors, to locally attenuate the effects of vasoconstrictors, while atorvastatin increased the efficacy of PVAT [135]. PAT has also been shown to release angiotensin and ET-1 when stimulated by angiotensin II, causing a significant vasoconstriction and an increase in reactive oxygen species $[136,137]$.

The low-grade inflammation discussed above may also be mediated by pro-inflammatory cytokines released by PAT. The epicardial adipose tissue, considered to be a localized department surrounding the heart and PAT of the coronary arteries, has been shown to produce TNF- $\alpha$, IL-1 $\beta$, IL-6, MCP-1, and IL-8 [127,138]. In addition to the chemotaxic properties of these inflammatory markers leading to the leukocyte migration to the vascular endothelium, inflammation can be mediated and increased by the amount of adipose tissue in the obese environment [127]. As demonstrated in Figure 1, these factors are released throughout the 
adipose tissue, however predominantly within the upper body and visceral cavity, easily accessible to the vascular system.

NEFA's released from the PAT tissue can interfere with insulin signaling and insulin mediated glucose uptake. This result can filter downstream of the large PAT influenced arteries and cause a reduction in capillary recruitment, through a vasoconstriction of pre-capillary arterioles, thus preventing capillary recruitment and muscle glucose uptake [122]. Insufficient glucose could limit muscle activity, as these downstream fibers would be metabolically inactive, suffering reduction in insulin signaling and possible ischemia [139].

The vasa vasorum represents a vascular network which integrates into the walls of larger arteries, and can facilitate the diffusion and transport of substrate within the arterial wall microenvironment. Recent studies have suggested that this might be an avenue through which inflammatory molecules can be introduced into the arterial wall, and contribute rapidly to alterations in vascular function [140,141]. This issue may be especially important within the abdomen, where fat deposits increase risk for a variety of confounding disease states and the mesenteric vasculature is abundant to aid in digestion. The vasa vasorum physically unites the cofactors related to obesity-related insulin resistance through an insulin resistant reduction in blood flow, impairment of insulin signaling, a reduction in NO dependent vasodilation, an increase of oxidant stress radicals, deposition of lipid into the surrounding tissues, and a chronic low-grade state of inflammation; specifically allowing PAT deposits to release adipokines at vascular beds for easy access to systemic effects, as evident in Figure $1[37,139,142]$.

\section{Interventions/Management of Obesity}

The principle issue related to obesity is the imbalance between energy expenditure and energy intake. Obesity results from more caloric intake than expenditure [17]. Therefore, the management of the disorder can be determined by changing one of the variables of the equation, either by decreasing caloric intake or increasing energy expenditure. Unfortunately, the obese condition can create additional pathophysiologies that interrupt this resolve.

Weight loss can show dramatic results to the self esteem, cardiovascular function, and arthritic symptoms experienced by an obese individual [143,144]. The cardiovascular effects can cascade throughout the negative cofactors associated with metabolic syndrome. Hodett, 2007, has shown improvements in vascular function of the microvessels of weight loss patients, including increases in eNOS expression, improvements in functional hyperemia, and vasodilation [72]. In addition, studies have shown an improvement in arterial compliance and distensibility [145]. Within the coronary system, weight loss has been shown to improve heart rate variability, left ventricular dysfunction (both systolic and diastolic) and mass, along with decreases in cardiac output, resting heart rate, and EKG intervals [146]. Weight loss has also shown beneficial results within the disease states of hypertension, dyslipidemia, and insulin resistance.

The methods by which individuals choose to lose weight, however, may be detrimental to their overall health. The physiological adaptations to obesity are especially important when exercise programs or medications are introduced. It must be considered that obesity causes persistent disproportionate elevations in cardiac filling pressures during exercise [147-149]. Patients must start slowly, in order to reverse some of the complications that have already developed; these patients have a baseline condition of rarefraction, therefore a limit in functional hyperemia, and increased risk of tissue hypoxia/ischemia, which may cause further muscle damage [58].

There are additional risks with non-exercise related weight loss techniques. Starvation tactics, such as liquid protein or low calorie, can cause tachycardia or an increase the EKG intervals, 
specifically of the QT interval [150]. There are many commercially available diet pills, with unknown or dangerous side effects, especially those that prevent absorption of various food products or are stated to increase the resting metabolic rate such as fenfluramine or dexfenfluramine. Surgical options are currently available as well and have shown significant improvements in weight loss, hypertension, insulin resistance, and arthritic conditions; however bariatric surgery can come with significant complication risk [4,151].

Obesity is reaching epidemic levels worldwide; as these this disease state progresses, alterations to the local endothelium and systemic cardiovascular system become evident. Within chronic cases of obesity, changes of the vasodilatory and vasoconstrictive mechanisms due to neural mediated changes, low-grade inflammation, or increases in radical oxidant scavenging accompanying confounding diseases significantly increase the morbidity and mortality rates associated. Future interventions should target the treatment of obesity prior to these systemic effects taking place.

\section{References}

1. Eckel RH, Kahn R, Robertson RM, Rizza RA. Preventing cardiovascular disease and diabetes: a call to action from the American Diabetes Association and the American Heart Association. Diabetes Care 2006;29:1697-1699. [PubMed: 16801605]

2. James PT. Obesity: the worldwide epidemic. Clin.Dermatol 2004;22:276-280. [PubMed: 15475226]

3. Ogden CL, Carroll MD, Curtin LR, McDowell MA, Tabak CJ, Flegal KM. Prevalence of overweight and obesity in the United States, 1999-2004. JAMA 2006;295:1549-1555. [PubMed: 16595758]

4. Powers KA, Rehrig ST, Jones DB. Financial impact of obesity and bariatric surgery. Med.Clin.North Am 2007;91:321-338. [PubMed: 17509381]ix.

5. Ogden CL, Yanovski SZ, Carroll MD, Flegal KM. The epidemiology of obesity. Gastroenterology 2007;132:2087-2102. [PubMed: 17498505]

6. Saranac L, Bjelakovic B, Stamenkovic H, Kamenov B. Orexitropic signaling proteins in obese children. Scientific World Journal 2007;7:1263-1271. [PubMed: 17721641]

7. Oner-Iyidogan Y, Kocak H, Gurdol F, Oner P, Issever H, Esin D. Circulating ghrelin levels in obese women: a possible association with hypertension. Scand.J.Clin.Lab Invest 2007;67:568-576. [PubMed: 17763194]

8. Cohen PG. Obesity in men: The hypogonadal-estrogen receptor relationship and its effect on glucose homeostasis. Med.Hypotheses 2007;70:358-360. [PubMed: 17825496]

9. Newbold RR, Padilla-Banks E, Snyder RJ, Jefferson WN. Perinatal exposure to environmental estrogens and the development of obesity. Mol.Nutr.Food Res 2007;51:912-917. [PubMed: 17604389]

10. Pasarica M, Zachwieja JJ, Dejonge L, Redman S, Smith SR. Effect of Growth Hormone on Body Composition and Visceral Adiposity in Middle Aged Men with Visceral Obesity. J.Clin.Endocrinol.Metab 2007;92:4265-4270. [PubMed: 17785361]

11. Pasarica M, Dhurandhar NV. Infectobesity: obesity of infectious origin. Adv.Food Nutr.Res 2007;52:61-102. [PubMed: 17425944]

12. Mutch DM, Clement K. Unraveling the genetics of human obesity. PLoS.Genet 2006;2:e188. [PubMed: 17196040]

13. Farooqi IS. Genetic and hereditary aspects of childhood obesity. Best.Pract.Res.Clin.Endocrinol.Metab 2005;19:359-374. [PubMed: 16150380]

14. Stunkard AJ, Foch TT, Hrubec Z. A twin study of human obesity. JAMA 1986;256:51-54. [PubMed: 3712713]

15. Levitsky DA. The non-regulation of food intake in humans: hope for reversing the epidemic of obesity. Physiol Behav 2005;86:623-632. [PubMed: 16263145]

16. Hamilton MT, Hamilton DG, Zderic TW. The Role of Low Energy Expenditure and Sitting on Obesity, Metabolic Syndrome, Type 2 Diabetes, and Cardiovascular Disease. Diabetes 2007;56:2655-2667. [PubMed: 17827399] 
17. Swinburn BA, Caterson I, Seidell JC, James WP. Diet, nutrition and the prevention of excess weight gain and obesity. Public Health Nutr 2004;7:123-146. [PubMed: 14972057]

18. Singer G, Granger N. Inflammatory responses underlying the microvascular dysfunction associated with obesity and insulin resistance. Microcirculation 2007;14:375-387. [PubMed: 17613809]

19. Poirier P, Giles TD, Bray GA, Hong Y, Stern JS, Pi-Sunyer FX, Eckel RH. Obesity and cardiovascular disease: pathophysiology, evaluation, and effect of weight loss. Arterioscler.Thromb.Vasc.Biol 2006;26:968-976. [PubMed: 16627822]

20. Kuchta KF. Pathophysiologic changes of obesity. Anesthesiol.Clin.North America 2005;23:421-429. [PubMed: 16005821]vi.

21. Antic V, Dulloo A, Montani JP. Multiple mechanisms involved in obesity-induced hypertension. Heart Lung Circ 2003;12:84-93. [PubMed: 16352114]

22. Kopelman PG. Obesity as a medical problem. Nature 2000;404:635-643. [PubMed: 10766250]

23. Martin LF, Robinson A, Moore BJ. Socioeconomic issues affecting the treatment of obesity in the new millennium. Pharmacoeconomics 2000;18:335-353. [PubMed: 15344303]

24. Rubenstein AH. Obesity: a modern epidemic. Trans.Am.Clin.Climatol.Assoc 2005;116:103-111. [PubMed: 16555609]

25. Funahashi T, Matsuzawa Y. Metabolic syndrome: Clinical concept and molecular basis. Ann.Med 2007:1-13.

26. Frisbee JC, Delp MD. Vascular function in the metabolic syndrome and the effects on skeletal muscle perfusion: lessons from the obese Zucker rat. Essays Biochem 2006;42:145-161. [PubMed: 17144886]

27. Eckel RH, Grundy SM, Zimmet PZ. The metabolic syndrome. Lancet 2005;365:1415-1428. [PubMed: 15836891]

28. Rankinen T, Zuberi A, Chagnon YC, Weisnagel SJ, Argyropoulos G, Walts B, Perusse L, Bouchard C. The human obesity gene map: the 2005 update. Obesity (Silver Spring) 2006;14:529-644. [PubMed: 16741264]

29. Suh JM, Zeve D, McKay R, Seo J, Salo Z, Li R, Wang M, Graff JM. Adipose is a conserved dosagesensitive antiobesity gene. Cell Metab 2007;6:195-207. [PubMed: 17767906]

30. Liu YJ, Xiao P, Xiong DH, Recker RR, Deng HW. Searching for obesity genes: progress and prospects. Drugs Today (Barc.) 2005;41:345-362. [PubMed: 16082432]

31. Snyder EE, Walts B, Perusse L, Chagnon YC, Weisnagel SJ, Rankinen T, Bouchard C. The human obesity gene map: the 2003 update. Obes.Res 2004;12:369-439. [PubMed: 15044658]

32. Yang W, Kelly T, He J. Genetic epidemiology of obesity. Epidemiol.Rev 2007;29:49-61. [PubMed: 17566051]

33. Rolls ET. Understanding the mechanisms of food intake and obesity. Obes.Rev 2007;8:67-72. [PubMed: 17316305]

34. Sone M, Osamura RY. Leptin and the pituitary. Pituitary 2001;4:15-23. [PubMed: 11824504]

35. Bray GA. The Zucker-fatty rat: a review. Fed.Proc 1977;36:148-153. [PubMed: 320051]

36. Johnson FK, Johnson RA, Durante W, Jackson KE, Stevenson BK, Peyton KJ. Metabolic syndrome increases endogenous carbon monoxide production to promote hypertension and endothelial dysfunction in obese Zucker rats. Am.J.Physiol Regul.Integr.Comp Physiol 2006;290:R601-R608. [PubMed: 16284090]

37. Frisbee JC. Hypertension-independent microvascular rarefaction in the obese Zucker rat model of the metabolic syndrome. Microcirculation 2005;12:383-392. [PubMed: 16020387]

38. Vaziri ND, Xu ZG, Shahkarami A, Huang KT, Rodriguez-Iturbe B, Natarajan R. Role of AT-1 receptor in regulation of vascular MCP-1, IL-6, PAI-1, MAP kinase, and matrix expressions in obesity. Kidney Int 2005;68:2787-2793. [PubMed: 16316354]

39. Eckel RH. Mechanisms of the components of the metabolic syndrome that predispose to diabetes and atherosclerotic CVD. Proc.Nutr.Soc 2007;66:82-95. [PubMed: 17343775]

40. Drel VR, Mashtalir N, Ilnytska O, Shin J, Li F, Lyzogubov VV, Obrosova IG. The leptin-deficient (ob/ob) mouse: a new animal model of peripheral neuropathy of type 2 diabetes and obesity. Diabetes 2006;55:3335-3343. [PubMed: 17130477] 
41. Lindstrom P. The physiology of obese-hyperglycemic mice [ob/ob mice]. Scientific World Journal 2007;7:666-685. [PubMed: 17619751]

42. Lu FL, Johnston RA, Flynt L, Theman TA, Terry RD, Schwartzman IN, Lee A, Shore SA. Increased pulmonary responses to acute ozone exposure in obese db/db mice. Am.J.Physiol Lung Cell Mol.Physiol 2006;290:L856-L865. [PubMed: 16373670]

43. Mustad VA, Demichele S, Huang YS, Mika A, Lubbers N, Berthiaume N, Polakowski J, Zinker B. Differential effects of n-3 polyunsaturated fatty acids on metabolic control and vascular reactivity in the type 2 diabetic ob/ob mouse. Metabolism 2006;55:1365-1374. [PubMed: 16979408]

44. Himms-Hagen J. On raising energy expenditure in ob/ob mice. Science 1997;276:1132-1133. [PubMed: 9173544]

45. Bergman RN, Kim SP, Hsu IR, Catalano KJ, Chiu JD, Kabir M, Richey JM, Ader M. Abdominal obesity: role in the pathophysiology of metabolic disease and cardiovascular risk. Am.J.Med 2007;120:S3-S8. [PubMed: 17296343]

46. Mensah GA, Mokdad AH, Ford E, Narayan KM, Giles WH, Vinicor F, Deedwania PC. Obesity, metabolic syndrome, and type 2 diabetes: emerging epidemics and their cardiovascular implications. Cardiol.Clin 2004;22:485-504. [PubMed: 15501618]

47. Wexler DJ, Grant RW, Wittenberg E, Bosch JL, Cagliero E, Delahanty L, Blais MA, Meigs JB. Correlates of health-related quality of life in type 2 diabetes. Diabetologia 2006;49:1489-1497. [PubMed: 16752167]

48. Hansson PO, Eriksson H, Welin L, Svardsudd K, Wilhelmsen L. Smoking and abdominal obesity: risk factors for venous thromboembolism among middle-aged men: "the study of men born in 1913". Arch.Intern.Med 1999;159:1886-1890. [PubMed: 10493318]

49. Goldhaber SZ, Grodstein F, Stampfer MJ, Manson JE, Colditz GA, Speizer FE, Willett WC, Hennekens $\mathrm{CH}$. A prospective study of risk factors for pulmonary embolism in women. JAMA 1997;277:642-645. [PubMed: 9039882]

50. Abularrage CJ, Sidawy AN, Aidinian G, Singh N, Weiswasser JM, Arora S. Evaluation of macrocirculatory endothelium-dependent and endothelium-independent vasoreactivity in vascular disease. Perspect.Vasc.Surg.Endovasc.Ther 2005;17:245-253. [PubMed: 16273167]

51. Wyman RA, Fraizer MC, Keevil JG, Busse KL, Aeschlimann SE, Korcarz CE, Stein JH. Ultrasounddetected carotid plaque as a screening tool for advanced subclinical atherosclerosis. Am.Heart J 2005;150:1081-1085. [PubMed: 16291002]

52. Ciccone M, Vettor R, Pannacciulli N, Minenna A, Bellacicco M, Rizzon P, Giorgino R, De, Pergola G. Plasma leptin is independently associated with the intima-media thickness of the common carotid artery. Int.J.Obes.Relat Metab Disord 2001;25:805-810. [PubMed: 11439293]

53. Heiss G, Sharrett AR, Barnes R, Chambless LE, Szklo M, Alzola C. Carotid atherosclerosis measured by B-mode ultrasound in populations: associations with cardiovascular risk factors in the ARIC study. Am.J.Epidemiol 1991;134:250-256. [PubMed: 1877584]

54. Ni M, Zhang M, Ding SF, Chen WQ, Zhang Y. Micro-ultrasound imaging assessment of carotid plaque characteristics in apolipoprotein-E knockout mice. Atherosclerosis 2007;197:64-71. [PubMed: 17870080]

55. Coleman R, Hayek T, Keidar S, Aviram M. A mouse model for human atherosclerosis: long-term histopathological study of lesion development in the aortic arch of apolipoprotein E-deficient (E0) mice. Acta Histochem 2006;108:415-424. [PubMed: 17007910]

56. Megnien JL, Simon A, Gariepy J, Denarie N, Cocaul M, Linhart A, Levenson J. Preclinical changes of extracoronary arterial structures as indicators of coronary atherosclerosis in men. J.Hypertens 1998;16:157-163. [PubMed: 9535142]

57. Stepp DW, Pollock DM, Frisbee JC. Low-flow vascular remodeling in the metabolic syndrome X. Am.J.Physiol Heart Circ.Physiol 2004;286:H964-H970. [PubMed: 14644764]

58. Frisbee JC. Obesity, insulin resistance, and microvessel density. Microcirculation 2007;14:289-298. [PubMed: 17613802]

59. Feletou M, Vanhoutte PM. Endothelial dysfunction: a multifaceted disorder (The Wiggers Award Lecture). Am.J.Physiol Heart Circ.Physiol 2006;291:H985-H1002. [PubMed: 16632549] 
60. Ignarro LJ, Buga GM, Wood KS, Byrns RE, Chaudhuri G. Endothelium-derived relaxing factor produced and released from artery and vein is nitric oxide. Proc.Natl.Acad.Sci.U.S.A 1987;84:92659269. [PubMed: 2827174]

61. Van Guilder GP, Hoetzer GL, Dengel DR, Stauffer BL, Desouza CA. Impaired endotheliumdependent vasodilation in normotensive and normoglycemic obese adult humans. J.Cardiovasc.Pharmacol 2006;47:310-313. [PubMed: 16495771]

62. Steinberg HO, Chaker H, Leaming R, Johnson A, Brechtel G, Baron AD. Obesity/insulin resistance is associated with endothelial dysfunction. Implications for the syndrome of insulin resistance. J.Clin.Invest 1996;97:2601-2610. [PubMed: 8647954]

63. Erdei N, Toth A, Pasztor ET, Papp Z, Edes I, Koller A, Bagi Z. High-fat diet-induced reduction in nitric oxide-dependent arteriolar dilation in rats: role of xanthine oxidase-derived superoxide anion. Am.J.Physiol Heart Circ.Physiol 2006;291:H2107-H2115. [PubMed: 16798827]

64. Frisbee JC, Stepp DW. Impaired NO-dependent dilation of skeletal muscle arterioles in hypertensive diabetic obese Zucker rats. Am.J.Physiol Heart Circ.Physiol 2001;281:H1304-H1311. [PubMed: 11514301]

65. Katakam PV, Tulbert CD, Snipes JA, Erdos B, Miller AW, Busija DW. Impaired insulin-induced vasodilation in small coronary arteries of Zucker obese rats is mediated by reactive oxygen species. Am.J.Physiol Heart Circ.Physiol 2005;288:H854-H860. [PubMed: 15650157]

66. Fulton D, Harris MB, Kemp BE, Venema RC, Marrero MB, Stepp DW. Insulin resistance does not diminish eNOS expression, phosphorylation, or binding to HSP-90. Am.J.Physiol Heart Circ.Physiol 2004;287:H2384-H2393. [PubMed: 15271670]

67. Karagiannis J, Reid JJ, Darby I, Roche P, Rand MJ, Li CG. Impaired nitric oxide function in the basilar artery of the obese Zucker rat. J.Cardiovasc.Pharmacol 2003;42:497-505. [PubMed: 14508235]

68. Eringa EC, Stehouwer CD, Roos MH, Westerhof N, Sipkema P. Selective resistance to vasoactive effects of insulin in muscle resistance arteries of obese Zucker (fa/fa) rats. Am.J.Physiol Endocrinol.Metab 2007;293:E1134-E1139. [PubMed: 17623751]

69. Picchi A, Gao X, Belmadani S, Potter BJ, Focardi M, Chilian WM, Zhang C. Tumor necrosis factoralpha induces endothelial dysfunction in the prediabetic metabolic syndrome. Circ.Res 2006;99:6977. [PubMed: 16741160]

70. Phillips SA, Sylvester FA, Frisbee JC. Oxidant stress and constrictor reactivity impair cerebral artery dilation in obese Zucker rats. Am.J.Physiol Regul.Integr.Comp Physiol 2005;288:R522-R530. [PubMed: 15514104]

71. Frisbee JC, Maier KG, Stepp DW. Oxidant stress-induced increase in myogenic activation of skeletal muscle resistance arteries in obese Zucker rats. Am.J.Physiol Heart Circ.Physiol 2002;283:H2160H2168. [PubMed: 12388303]

72. Hodnett BL, Hester RL. Regulation of muscle blood flow in obesity. Microcirculation 2007;14:273288. [PubMed: 17613801]

73. Frisbee JC. Impaired dilation of skeletal muscle microvessels to reduced oxygen tension in diabetic obese Zucker rats. Am.J.Physiol Heart Circ.Physiol 2001;281:H1568-H1574. [PubMed: 11557545]

74. Chinen I, Shimabukuro M, Yamakawa K, Higa N, Matsuzaki T, Noguchi K, Ueda S, Sakanashi M, Takasu N. Vascular lipotoxicity: endothelial dysfunction via fatty-acid- induced reactive oxygen species overproduction in obese Zucker diabetic fatty rats. Endocrinology 2007;148:160-165. [PubMed: 17023526]

75. Xiang L, Naik JS, Hodnett BL, Hester RL. Altered arachidonic acid metabolism impairs functional vasodilation in metabolic syndrome. Am.J.Physiol Regul.Integr.Comp Physiol 2006;290:R134R138. [PubMed: 16166209]

76. Henrion D. Pressure and flow-dependent tone in resistance arteries. Role of myogenic tone. Arch.Mal Coeur Vaiss 2005;98:913-921. [PubMed: 16231579]

77. Meyer AA, Kundt G, Steiner M, Schuff-Werner P, Kienast W. Impaired flow-mediated vasodilation, carotid artery intima-media thickening, and elevated endothelial plasma markers in obese children: the impact of cardiovascular risk factors. Pediatrics 2006;117:1560-1567. [PubMed: 16651309]

78. Hamdy O, Ledbury S, Mullooly C, Jarema C, Porter S, Ovalle K, Moussa A, Caselli A, Caballero AE, Economides PA, Veves A, Horton ES. Lifestyle modification improves endothelial function in 
obese subjects with the insulin resistance syndrome. Diabetes Care 2003;26:2119-2125. [PubMed: 12832323]

79. Raitakari M, Ilvonen T, Ahotupa M, Lehtimaki T, Harmoinen A, Suominen P, Elo J, Hartiala J, Raitakari OT. Weight reduction with very-low-caloric diet and endothelial function in overweight adults: role of plasma glucose. Arterioscler.Thromb.Vasc.Biol 2004;24:124-128. [PubMed: 14656740]

80. Dandona P, Aljada A, Chaudhuri A. Vascular reactivity and thiazolidinediones. Am.J.Med 2003;115:81S-86S. [PubMed: 14678871]

81. Stepp DW, Boesen EI, Sullivan JC, Mintz JD, Hair CD, Pollock DM. Obesity augments vasoconstrictor reactivity to angiotensin II in the renal circulation of the Zucker rat. Am.J.Physiol Heart Circ.Physiol 2007;293:H2537-H2542. [PubMed: 17693541]

82. Cardillo C, Campia U, Bryant MB, Panza JA. Increased activity of endogenous endothelin in patients with type II diabetes mellitus. Circulation 2002;106:1783-1787. [PubMed: 12356630]

83. Ferri C, Bellini C, Desideri G, Baldoncini R, Properzi G, Santucci A, De, Mattia G. Circulating endothelin-1 levels in obese patients with the metabolic syndrome. Exp.Clin.Endocrinol.Diabetes 1997;105:38-40. [PubMed: 9288542]

84. Wilson JR, Kapoor SC. Contribution of prostaglandins to exercise-induced vasodilation in humans. Am.J.Physiol 1993;265:H171-H175. [PubMed: 8342631]

85. Beaty O III, Donald DE. Contribution of prostaglandins to muscle blood flow in anesthetized dogs at rest, during exercise, and following inflow occlusion. Circ.Res 1979;44:67-75. [PubMed: 363302]

86. Young EW, Sparks HV. Prostaglandin E release from dog skeletal muscle during restricted flow exercise. Am.J.Physiol 1979;236:H596-H599. [PubMed: 434226]

87. Kilbom A, Wennmalm A. Endogenous prostaglandins as local regulators of blood flow in man: effect of indomethacin on reactive and functional hyperaemia. J.Physiol 1976;257:109-121. [PubMed: 948043]

88. Prasad A, Husain S, Quyyumi AA. Abnormal flow-mediated epicardial vasomotion in human coronary arteries is improved by angiotensin-converting enzyme inhibition: a potential role of bradykinin. J.Am.Coll.Cardiol 1999;33:796-804. [PubMed: 10080484]

89. Knudson JD, Dincer UD, Bratz IN, Sturek M, Dick GM, Tune JD. Mechanisms of coronary dysfunction in obesity and insulin resistance. Microcirculation 2007;14:317-338. [PubMed: 17613805]

90. Esler M, Rumantir M, Wiesner G, Kaye D, Hastings J, Lambert G. Sympathetic nervous system and insulin resistance: from obesity to diabetes. Am.J.Hypertens 2001;14:304S-309S. [PubMed: 11721888]

91. Frisbee JC. Vascular adrenergic tone and structural narrowing constrain reactive hyperemia in skeletal muscle of obese Zucker rats. Am.J.Physiol Heart Circ.Physiol 2006;290:H2066-H2074. [PubMed: 16373580]

92. Schreihofer AM, Hair CD, Stepp DW. Reduced plasma volume and mesenteric vascular reactivity in obese Zucker rats. Am.J.Physiol Regul.Integr.Comp Physiol 2005;288:R253-R261. [PubMed: 15345476]

93. Frisbee JC. Impaired skeletal muscle perfusion in obese Zucker rats. Am.J.Physiol Regul.Integr.Comp Physiol 2003;285:R1124-R1134. [PubMed: 12855417]

94. Ungvari Z, Csiszar A, Bagi Z, Koller A. Impaired nitric oxide-mediated flow-induced coronary dilation in hyperhomocysteinemia: morphological and functional evidence for increased peroxynitrite formation. Am.J.Pathol 2002;161:145-153. [PubMed: 12107099]

95. Brzezinska AK, Gebremedhin D, Chilian WM, Kalyanaraman B, Elliott SJ. Peroxynitrite reversibly inhibits $\mathrm{Ca}(2+)$-activated $\mathrm{K}(+)$ channels in rat cerebral artery smooth muscle cells. Am.J.Physiol Heart Circ.Physiol 2000;278:H1883-H1890. [PubMed: 10843885]

96. Agapitov AV, Correia ML, Sinkey CA, Dopp JM, Haynes WG. Impaired skeletal muscle and skin microcirculatory function in human obesity. J.Hypertens 2002;20:1401-1405. [PubMed: 12131537]

97. Vollenweider P, Randin D, Tappy L, Jequier E, Nicod P, Scherrer U. Impaired insulin-induced sympathetic neural activation and vasodilation in skeletal muscle in obese humans. J.Clin.Invest 1994;93:2365-2371. [PubMed: 8200969] 
98. Naik JS, Xiang L, Hester RL. Enhanced role for RhoA-associated kinase in adrenergic-mediated vasoconstriction in gracilis arteries from obese Zucker rats. Am.J.Physiol Regul.Integr.Comp Physiol 2006;290:R154-R161. [PubMed: 16141308]

99. Stepp DW, Frisbee JC. Augmented adrenergic vasoconstriction in hypertensive diabetic obese Zucker rats. Am.J.Physiol Heart Circ.Physiol 2002;282:H816-H820. [PubMed: 11834474]

100. Lambert E, Straznicky N, Eikelis N, Esler M, Dawood T, Masuo K, Schlaich M, Lambert G. Gender differences in sympathetic nervous activity: influence of body mass and blood pressure. J.Hypertens 2007;25:1411-1419. [PubMed: 17563563]

101. Carlson SH, Shelton J, White CR, Wyss JM. Elevated sympathetic activity contributes to hypertension and salt sensitivity in diabetic obese Zucker rats. Hypertension 2000;35:403-408. [PubMed: 10642332]

102. Toblli JE, Cao G, DeRosa G, Di, Gennaro F, Forcada P. Angiotensin-converting enzyme inhibition and angiogenesis in myocardium of obese Zucker rats. Am.J.Hypertens 2004;17:172-180. [PubMed: 14751661]

103. Silha JV, Krsek M, Sucharda P, Murphy LJ. Angiogenic factors are elevated in overweight and obese individuals. Int.J.Obes.(Lond) 2005;29:1308-1314. [PubMed: 15953938]

104. Gealekman O, Brodsky SV, Zhang F, Chander PN, Friedli C, Nasjletti A, Goligorsky MS. Endothelial dysfunction as a modifier of angiogenic response in Zucker diabetic fat rat: amelioration with Ebselen. Kidney Int 2004;66:2337-2347. [PubMed: 15569324]

105. Baron AD. Hemodynamic actions of insulin. Am.J.Physiol 1994;267:E187-E202. [PubMed: 8074198]

106. Rattigan S, Bussey CT, Ross RM, Richards SM. Obesity, insulin resistance, and capillary recruitment. Microcirculation 2007;14:299-309. [PubMed: 17613803]

107. Dohm GL, Tapscott EB, Pories WJ, Dabbs DJ, Flickinger EG, Meelheim D, Fushiki T, Atkinson SM, Elton CW, Caro JF. An in vitro human muscle preparation suitable for metabolic studies. Decreased insulin stimulation of glucose transport in muscle from morbidly obese and diabetic subjects. J.Clin.Invest 1988;82:486-494. [PubMed: 3403714]

108. Crettaz M, Prentki M, Zaninetti D, Jeanrenaud B. Insulin resistance in soleus muscle from obese Zucker rats. Involvement of several defective sites. Biochem.J 1980;186:525-534. [PubMed: 6990920]

109. Clerk LH, Vincent MA, Jahn LA, Liu Z, Lindner JR, Barrett EJ. Obesity blunts insulin-mediated microvascular recruitment in human forearm muscle. Diabetes 2006;55:1436-1442. [PubMed: 16644702]

110. Wallis MG, Wheatley CM, Rattigan S, Barrett EJ, Clark AD, Clark MG. Insulin-mediated hemodynamic changes are impaired in muscle of Zucker obese rats. Diabetes 2002;51:3492-3498. [PubMed: 12453905]

111. Stepp DW, Belin De Chantemele EJ. Structural remodeling in the limb circulation: impact of obesity and diabetes. Microcirculation 2007;14:311-316. [PubMed: 17613804]

112. McMillan DE. Deterioration of the microcirculation in diabetes. Diabetes 1975;24:944-957. [PubMed: 170155]

113. Zebekakis PE, Nawrot T, Thijs L, Balkestein EJ, van, der Heijden-Spek, Van Bortel LM, StruijkerBoudier HA, Safar ME, Staessen JA. Obesity is associated with increased arterial stiffness from adolescence until old age. J.Hypertens 2005;23:1839-1846. [PubMed: 16148607]

114. Feener EP, King GL. Vascular dysfunction in diabetes mellitus. Lancet 1997;350:SI9-SI13. [PubMed: 9250277]

115. Fossum E, Hoieggen A, Moan A, Rostrup M, Nordby G, Kjeldsen SE. Relationship between insulin sensitivity and maximal forearm blood flow in young men. Hypertension 1998;32:838-843. [PubMed: 9822441]

116. Piiper J. Modeling of oxygen transport to skeletal muscle: blood flow distribution, shunt, and diffusion. Adv.Exp.Med.Biol 1992;316:3-10. [PubMed: 1288091]

117. Schindler TH, Cardenas J, Prior JO, Facta AD, Kreissl MC, Zhang XL, Sayre J, Dahlbom M, Licinio J, Schelbert HR. Relationship between increasing body weight, insulin resistance, inflammation, adipocytokine leptin, and coronary circulatory function. J.Am.Coll.Cardiol 2006;47:1188-1195. [PubMed: 16545651] 
118. Vanhoutte PM. Endothelial control of vasomotor function: from health to coronary disease. Circ.J 2003;67:572-575. [PubMed: 12845177]

119. Schiffrin EL. Vascular and cardiac benefits of angiotensin receptor blockers. Am.J.Med 2002;113:409-418. [PubMed: 12401536]

120. Lee YH, Pratley RE. The evolving role of inflammation in obesity and the metabolic syndrome. Curr.Diab.Rep 2005;5:70-75. [PubMed: 15663921]

121. Fantuzzi G. Adipose tissue, adipokines, and inflammation. J.Allergy Clin.Immunol 2005;115:911919. [PubMed: 15867843]

122. Eringa EC, Bakker W, Smulders YM, Serne EH, Yudkin JS, Stehouwer CD. Regulation of vascular function and insulin sensitivity by adipose tissue: focus on perivascular adipose tissue.

Microcirculation 2007;14:389-402. [PubMed: 17613810]

123. Knight SF, Imig JD. Obesity, insulin resistance, and renal function. Microcirculation 2007;14:349_ 362. [PubMed: 17613807]

124. Nakagawa K, Higashi Y, Sasaki S, Oshima T, Matsuura H, Chayama K. Leptin causes vasodilation in humans. Hypertens. Res 2002;25:161-165. [PubMed: 12047029]

125. Matsuda K, Teragawa H, Fukuda Y, Nakagawa K, Higashi Y, Chayama K. Leptin causes nitricoxide independent coronary artery vasodilation in humans. Hypertens.Res 2003;26:147-152. [PubMed: 12627874]

126. Johnson RL, Williams SM, Spruill IJ. Genomics, nutrition, obesity, and diabetes. J.Nurs.Scholarsh 2006;38:11-18. [PubMed: 16579318]

127. Thalmann S, Meier CA. Local adipose tissue depots as cardiovascular risk factors. Cardiovasc.Res 2007;75:690-701. [PubMed: 17412312]

128. Verlohren S, Dubrovska G, Tsang SY, Essin K, Luft FC, Huang Y, Gollasch M. Visceral periadventitial adipose tissue regulates arterial tone of mesenteric arteries. Hypertension 2004;44:271-276. [PubMed: 15302842]

129. Takemori K, Gao YJ, Ding L, Lu C, Su LY, An WS, Vinson C, Lee RM. Elevated blood pressure in transgenic lipoatrophic mice and altered vascular function. Hypertension 2007;49:365-372. [PubMed: 17200435]

130. Gao YJ, Lu C, Su LY, Sharma AM, Lee RM. Modulation of vascular function by perivascular adipose tissue: the role of endothelium and hydrogen peroxide. Br.J.Pharmacol 2007;151:323-331. [PubMed: 17384669]

131. Chignier E, Eloy R. Adventitial resection of small artery provokes endothelial loss and intimal hyperplasia. Surg.Gynecol.Obstet 1986;163:327-334. [PubMed: 3764638]

132. Moos MP, John N, Grabner R, Nossmann S, Gunther B, Vollandt R, Funk CD, Kaiser B, Habenicht AJ. The lamina adventitia is the major site of immune cell accumulation in standard chow-fed apolipoprotein E-deficient mice. Arterioscler.Thromb.Vasc.Biol 2005;25:2386-2391. [PubMed: 16179593]

133. Gollasch M, Dubrovska G. Paracrine role for periadventitial adipose tissue in the regulation of arterial tone. Trends Pharmacol.Sci 2004;25:647-653. [PubMed: 15530643]

134. Soltis EE, Cassis LA. Influence of perivascular adipose tissue on rat aortic smooth muscle responsiveness. Clin.Exp.Hypertens.A 1991;13:277-296. [PubMed: 2065467]

135. Gao YJ. Dual modulation of vascular function by perivascular adipose tissue and its potential correlation with adiposity/lipoatrophy-related vascular dysfunction. Curr.Pharm.Des 2007;13:2185-2192. [PubMed: 17627551]

136. An SJ, Boyd R, Wang Y, Qiu X, Wang HD. Endothelin-1 expression in vascular adventitial fibroblasts. Am.J.Physiol Heart Circ.Physiol 2006;290:H700-H708. [PubMed: 16113066]

137. Rogerson FM, Chai SY, Schlawe I, Murray WK, Marley PD, Mendelsohn FA. Presence of angiotensin converting enzyme in the adventitia of large blood vessels. J.Hypertens 1992;10:615620. [PubMed: 1321187]

138. Mazurek T, Zhang L, Zalewski A, Mannion JD, Diehl JT, Arafat H, Sarov-Blat L, O'Brien S, Keiper EA, Johnson AG, Martin J, Goldstein BJ, Shi Y. Human epicardial adipose tissue is a source of inflammatory mediators. Circulation 2003;108:2460-2466. [PubMed: 14581396] 
139. Kim JK, Michael MD, Previs SF, Peroni OD, Mauvais-Jarvis F, Neschen S, Kahn BB, Kahn CR, Shulman GI. Redistribution of substrates to adipose tissue promotes obesity in mice with selective insulin resistance in muscle. J.Clin.Invest 2000;105:1791-1797. [PubMed: 10862794]

140. Sengenes C, Lolmede K, Zakaroff-Girard A, Busse R, Bouloumie A. Preadipocytes in the human subcutaneous adipose tissue display distinct features from the adult mesenchymal and hematopoietic stem cells. J.Cell Physiol 2005;205:114-122. [PubMed: 15880450]

141. Herrmann J, Lerman LO, Rodriguez-Porcel M, Holmes DR Jr, Richardson DM, Ritman EL, Lerman A. Coronary vasa vasorum neovascularization precedes epicardial endothelial dysfunction in experimental hypercholesterolemia. Cardiovasc.Res 2001;51:762-766. [PubMed: 11530109]

142. Weisberg SP, McCann D, Desai M, Rosenbaum M, Leibel RL, Ferrante AW Jr. Obesity is associated with macrophage accumulation in adipose tissue. J.Clin.Invest 2003;112:1796-1808. [PubMed: 14679176]

143. Blaine BE, Rodman J, Newman JM. Weight loss treatment and psychological wellbeing: a review and meta-analysis. J.Health Psychol 2007;12:66-82. [PubMed: 17158841]

144. Christensen R, Bartels EM, Astrup A, Bliddal H. Effect of weight reduction in obese patients diagnosed with knee osteoarthritis: a systematic review and meta-analysis. Ann.Rheum.Dis 2007;66:433-439. [PubMed: 17204567]

145. Dengel DR, Kelly AS, Olson TP, Kaiser DR, Dengel JL, Bank AJ. Effects of weight loss on insulin sensitivity and arterial stiffness in overweight adults. Metabolism 2006;55:907-911. [PubMed: 16784962]

146. Poirier P, Giles TD, Bray GA, Hong Y, Stern JS, Pi-Sunyer FX, Eckel RH. Obesity and cardiovascular disease: pathophysiology, evaluation, and effect of weight loss: an update of the 1997 American Heart Association Scientific Statement on Obesity and Heart Disease from the Obesity Committee of the Council on Nutrition, Physical Activity, and Metabolism. Circulation 2006;113:898-918. [PubMed: 16380542]

147. Alexander JK, Peterson KL. Cardiovascular effects of weight reduction. Circulation 1972;45:310318. [PubMed: 4257897]

148. Kaltman AJ, Goldring RM. Role of circulatory congestion in the cardiorespiratory failure of obesity. Am.J.Med 1976;60:645-653. [PubMed: 1020753]

149. Backman L, Freyschuss U, Hallberg D, Melcher A. Reversibility of cardiovascular changes in extreme obesity. Effects of weight reduction through jejunoileostomy. Acta Med.Scand 1979;205:367-373. [PubMed: 443075]

150. Rasmussen LH, Andersen T. The relationship between QTc changes and nutrition during weight loss after gastroplasty. Acta Med.Scand 1985;217:271-275. [PubMed: 3993440]

151. Mathier MA, Ramanathan RC. Impact of obesity and bariatric surgery on cardiovascular disease. Med.Clin.North Am 2007;91:415-4xi. [PubMed: 17509386] 


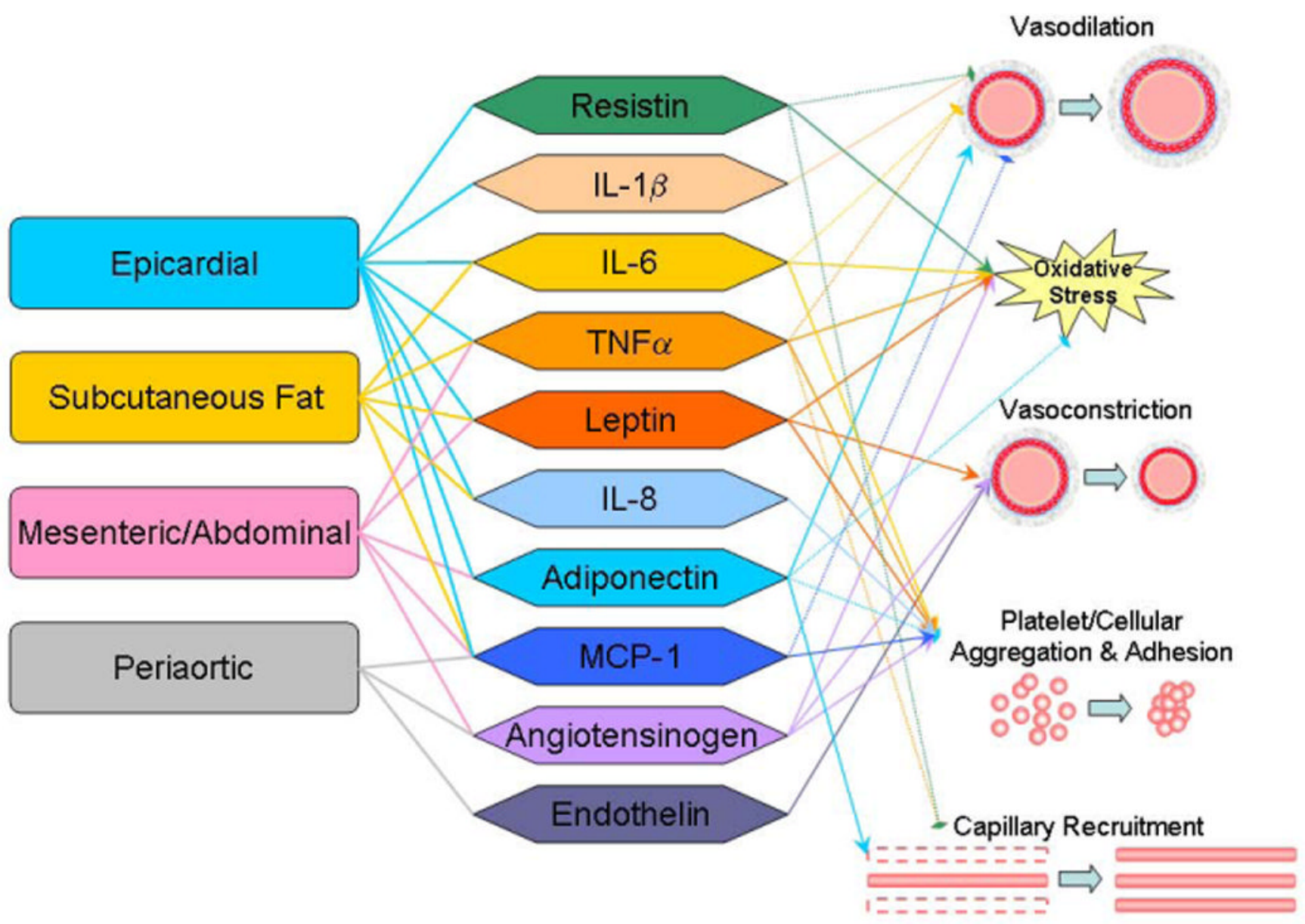

Figure 1.

A schematic representation of adipose tissue depositions, the adipokines, inflammatory markers and other factors that are released from these tissues, and their identified impact on elements of vascular function. Pointed arrows indicate potentiating effects on vascular outcome, while flat headed arrows indicate inhibitory effects on vascular outcome. 